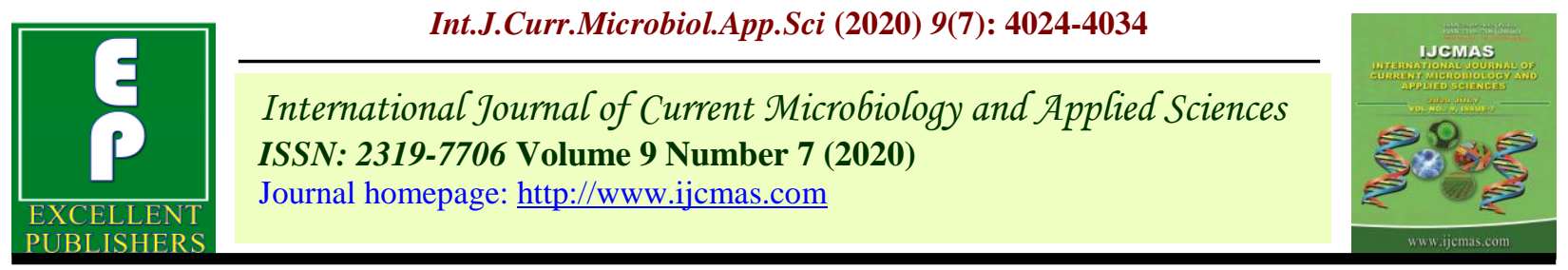

\title{
Response of Growth, Yield and Yield Attributes of Popcorn (Zea mays everta) to Organic and Inorganic Sources of Nutrients
}

\author{
Sadaf Iqbal $^{1}$, Zahida Rashid $^{2}$, Manzoor Ganai ${ }^{3}$, A. A. Saad ${ }^{1}$, R. H. Kanth ${ }^{1}$, Rais Bhat ${ }^{1}$, \\ Tahir Sheikh ${ }^{1}$, Javaid Ahmad Bhat ${ }^{4}$ and Tanveer ${ }^{1}$
}

${ }^{I}$ Division of Agronomy, SKUAST-K, Wadura Campus, Sopore, Jammu and Kashmir, India

${ }^{2}$ Dryland Agriculture Research Station Skuast-K Jammu and Kashmir, India

${ }^{3}$ Mountain Rice Research Institute Khudwani, Jammu and Kashmir, India

${ }^{4}$ KVK, Ganderbal SKUAST-K Shuhama, 190006, India

*Corresponding author

\section{A B S T R A C T}

\begin{tabular}{|l|}
\hline Ke y w o r d s \\
$\begin{array}{l}\text { Biofertilizers, FYM, } \\
\text { Popcorn, Poultry } \\
\text { manure, RDF, } \\
\text { Vermi-compost }\end{array}$ \\
\hline Article Info \\
\hline $\begin{array}{l}\text { Accepted: } \\
\text { 18 June 2020 } \\
\text { Available Online: } \\
\text { 10 July 2020 }\end{array}$ \\
\hline
\end{tabular}

In order to study the effect of different organic and inorganic sources of nutrients on growth, yield and yield attributes of popcorn, an experiment was conducted at crop research farm of Division of Agronomy, Faculty of Agriculture, Sher-e-Kashmir University of Agricultural Sciences and Technology of Kashmir, Wadura during kharif 2017. The results indicated that the application of RDF $\left(\mathrm{N}_{120} \mathrm{P}_{60} \mathrm{~K}_{40}\right) \mathrm{kg} \mathrm{ha}^{-1}$ recorded highest growth and yield parameters viz. plant height $(187.58 \mathrm{~cm})$, number of functional leaves (12.05), leaf area index (6.68), dry matter accumulation (139.9 q ha ${ }^{-1}$ ), yield attributes \{number of grains per cob (480.0) and 1000 grain weight $(193 \mathrm{~g})\}$, grain yield $\left(38.8 \mathrm{q} \mathrm{ha}^{-1}\right)$, stover yield $\left(110.2 \mathrm{q} \mathrm{ha}^{-1)}\right.$ and benefit :cost ratio but was at par with $75 \%$ RDF + FYM @ 10 ha $^{-1}+$ AZO + PSB + KSB $\left(\mathrm{T}_{7}\right)$ while significantly lowest value of above mentioned parameters was found in control $\left(\mathrm{T}_{1}\right)$. No significant differences were found in rest of the treatments. So, it was considered that application of 75\% RDF + FYM @ $10 \mathrm{t} \mathrm{ha}^{-1}+\mathrm{AZO}+\mathrm{PSB}+\mathrm{KSB}$ over RDF should be recommended because of its considerable influence on improving soil health and maintaining ecological balance and also with better net and gross returns.

\section{Introduction}

Globally maize is grown on an area of 177.96 $\mathrm{m}$ ha, production is about 963.32 (million tonnes) with productivity of $5.41 \mathrm{t} \mathrm{ha}^{-1}$ (FAO, 2015). In India it is cultivated on $9.2 \mathrm{~m}$ ha producing about of 24.17 (million tonnes) with productivity of $2.56 \mathrm{t} \mathrm{ha}^{-1}$ (Directorate of Economics and Statistics, 2014-15). In the state of Jammu and Kashmir, maize is the second most important crop after rice and is a staple food in some tribal areas. Out of the total land area of 3.10 lakh ha under maize in the state, Kashmir accounts for about 1 lakh ha and the productivity is around $1.7 \mathrm{t} \mathrm{ha}^{-1}$ (DES, 2015).Diverse types of corns flint corn, dent corn, flour corn, sweet corn, pop corn etc. are grown in India of which pop corn is the only corn that pops. Pop corn (Zea mays everta) an important type of corn which is prominently used for popped form; green cobs for table purpose and widely used in 
preparation of snacks in meals in different parts of world. In addition, its shoot parts are used as green fodder due to absence of HCN. Demand of pop corn is increasing day by day with the changing food preferences in Indian life style. Adopting such type of crops, farmers may be able to get higher profitability as compared to traditional crops. Air-popped pop corn is naturally high in dietary fibre and antioxidants, low in calories and fat and sugar free and sodium. Pop corn is rich source of thiamine, manganese, magnesium and many other nutrients. This can make it an attractive snack for people with dietary restrictions on the intake of calories, fat, sugar and sodium. The productivity of maize is highly dependent on its nutrient management. Maize is a heavy feeder crop and because of this nature, very efficient converter of solar energy into dry matter (Awotundun, 2005). It is well perceived that for achieving high productivity in pop corn, an adequate and balanced supply of essential nutrients is required. The use of chemical fertilizers is the quickest and surest way of boosting crop production. However, the continued application of chemical fertilizers leads to deterioration of soil health with reduced organic carbon and increased multi-nutrient deficiencies. As such the judicious use of fertilizers from different sources in the crop will maintain the environmental sustainability for generations without affecting the environmental health (Dadarwal et al., 2009). Maintaining and improving soil quality is thus crucial if agricultural productivity and environmental quality are to be sustained for future generations (Reeves, 1997). The use of organic manures has been proposed as one of the main pillars of sustainable agriculture. The application of organic sources of nutrients not only helps in enhancing the productivity but has the beneficial effect on soil properties as well (Pathak et al., 2005). Organic manures induce improvement in physical, chemical, and biological properties of soil. Nutrients available in organic manures are released slowly, remain in the soil for longer time and are available to plants, thereby, maintain soil fertility and enhance the yield (Belay et al., 2001). These are valuable resources as they provide large amounts of macro and micro nutrients for crop growth and eco-friendly alternative to mineral fertilizers. Building up of these macro and micro nutrients, counteracting deleterious effects of soil acidity, salinity and alkalinity and substances of soil health are the key beneficial effects associated with organic manures. The organic sources besides supplying $\mathrm{N}, \mathrm{P}$ and $\mathrm{K}$ also make unavailable sources of elemental nitrogen, bound phosphates, micro-nutrients and decomposed plant residues into available forms to facilitate plants to absorb the nutrients. Whereas mineral fertilizer and organic manures used separately or combined have beneficial effects upon soil and crop, their combined use is expected to yield rewarding dividends (Rayar, 2000). According to Rayar (2000), application of mineral fertilizers alone to boost the yield may be favorable for few growing seasons. Such agronomic practice would undoubtedly lead to regrettable consequences. This might involve complete crop failure or drastic reduction in yield due-largely to non-supply of some vital secondary and trace elements to soil because of exhaustive nature of the crop and initiation of soil degradation. On the other hand, by combining application of organic manures and mineral fertilizers, the yield is expected to stabilize over the years, indicating a substantial improvement in soil fertility.

\section{Materials and Methods}

The present study was carried out during the rainy (kharif) season of 2017 at Research Farm of the Division of Agronomy, Faculty of Agriculture and Regional Research Station, Wadura, SKUAST-K. Jammu and Kashmir (latitude $34^{\circ} 172^{\prime} \mathrm{N}$, longitude $74^{\circ} 332^{\prime} \mathrm{E}$ and 
at an altitude of 1524 meters above mean sea level. The experimental site was well drained with uniform topography. Climatically the experimental site falls in temperate zone of north western Himalaya characterized by hot summers and very cold winters. The average annual precipitation is $812 \mathrm{~mm}$ (average of past 30 years) most of which is received from December to April in the form of snow and rains. The maximum and minimum temperatures were 24.67 and $10.05{ }^{\circ} \mathrm{C}$, respectively and the total precipitation amounted to $232.7 \mathrm{~mm}$ during crop growth period of 2017. The total number of sunshine hours recorded during the crop growth period was 328 hours and the mean maximum and minimum relative humidity were 79.75 and $56.04 \%$, respectively during the crop growth period. The soil of the experimental field was silty-clay loam in texture, medium in organic carbon, available nitrogen, phosphorous and potassium with neutral $\mathrm{pH}$ and normal electrical conductivity (Table 1).

The experiment comprising of twelve treatments including control was laid out in a Randomized Block Design with three replications. The twelve treatments are $\left(\mathrm{T}_{1}=\right.$ Absolute control, $\mathrm{T}_{2}=\mathrm{RDF}(120: 60: 40 \mathrm{~N}$, $\mathrm{P}_{2} \mathrm{O}_{5}$ and $\mathrm{K}_{2} \mathrm{O} \mathrm{kg} \mathrm{ha}{ }^{-1}$ respectively), $\mathrm{T}_{3}=\mathrm{FYM}$ @ $15 \mathrm{t} \mathrm{ha}^{-1}, \mathrm{~T}_{4}=$ Vermi-compost @ $5 \mathrm{t} \mathrm{ha}^{-1}, \mathrm{~T}_{5}$ $=$ Poultry manure @ $5 \mathrm{t} \mathrm{ha}^{-1}, \mathrm{~T}_{6}=75 \% \mathrm{RDF}$ +FYM@10 t ha ${ }^{-1}, \mathrm{~T}_{7}=75 \% \mathrm{RDF}+\mathrm{FYM} @$ $10 \mathrm{t} \mathrm{ha}^{-1}+$ Azospirillum $+\mathrm{PSB}+\mathrm{KSB}, \mathrm{T}_{8}=$ $\mathrm{FYM} @ 10 \mathrm{t} \mathrm{ha}^{-1}+$ Azospirillum, $\mathrm{T}_{9}=\mathrm{FYM}$ @ $10 \mathrm{t} \mathrm{ha}^{-1}+$ Azospirillum + PSB, $\mathrm{T}_{10}=\mathrm{FYM}$ @ $10 \mathrm{t} \mathrm{ha}^{-1}+$ Azospirillum + PSB + KSB, $\mathrm{T}_{11}=$ Vermi-compost @ $5 \mathrm{t} \mathrm{ha}^{-1}+$ Azospirillum $+\mathrm{PSB}+\mathrm{KSB}, \mathrm{T}_{12}=$ Poultry manure @ $5 \mathrm{tha}$ $1+$ Azospirillum + PSB + KSB. The field was prepared by giving 2-3 ploughing with rotavator so as to crush the clods and hard pans. Stubbles and weeds etc. were removed from the field followed by equal number of harrowings. After leveling the experimental field, block/replication borders, plot bunds and irrigation channels were made manually as per the layout plan. The required quantity of different manures viz. farm yard manure, poultry manure and vermi-compost as per the treatments was applied in field 15 days before sowing. Urea, Diammonium phosphate and muriate of potash were used as source of nitrogen, phosphorus and potassium, respectively in the form of chemical fertilizers. The nitrogen was applied in three splits $50 \%$ as basal, 25\% knee high and $25 \%$ tasselling stage. While, full dose of phosphorus and potassium were applied as basal as per the treatment details.

The seed of KDPC-2 was sown at the rate of $18 \mathrm{~kg} \mathrm{ha}^{-1}$ in rows $60 \mathrm{~cm}$ apart with plant to plant spacing of $20 \mathrm{~cm}$ which gave a plant population of 83333.00 plants ha ${ }^{-1}$. Seed was sown uniformly at a depth of $5-6 \mathrm{~cm}$. Thinning was done after about 3 weeks of sowing to maintain plant to plant spacing. Two hand weedings were done at 30 and 50 days after sowing. Row-wise detasseling was carried out soon after tassel emergence in order to maintain quality of pop corn. However, while removing tassels, care was taken not to damage flag leaf which would otherwise affect the net photosynthesis.

For studying the growth and yield attributes, three plants were randomly selected and tagged from penultimate rows of each plot and the average for every parameter was worked out and recorded at different growth stages of pop corn at 15 days interval from the date of sowing. The plant height was taken from the base of plant to fully opened top leaf before tasseling, whereas after tasseling, the height was measured up to the top of the tassel. The number of green leaves per plant was recorded by counting the fully opened green leaves in each net plot. By using meter scale, length and breadth of leaves in each plot was measured and the value obtained was multiplied by a constant 0.73309 (Chand and 
Sharma, 1976) to get the actual leaf area. The leaf area index was worked out as ratio of total leaf area to the land area. For dry matter accumulation at 15 days interval the plants selected from sowing date upto plucking stage were sun-dried. After sun drying, these plants were oven dried at $70^{\circ} \mathrm{C}$ temperature till the constant weight was obtained and weights were recorded by using electronic balance.The numbers of cobs obtained from the six randomly selected plants were counted and calculated for one ha area. The total number of grains in a row from previously selected six cobs were counted and averaged out to get number of grains row $^{-1}$. The total number of gain rows per cob were counted from six randomly selected plants and averaged to get number of grains rows $\mathrm{cob}^{-}$ ${ }^{1}$.Grains from the sun dried cobs of six plants were separated and weighed. The average value was calculated to get the grain weight per cob and expressed in $\mathrm{g}$. A representative sample of 1000-grains was taken from the grain yield of each plot and dried. The weight of oven dried sample was recorded to represent 1000-grain weight.

The grain yield of each net plot was thoroughly cleaned and sun dried. The yield from each plot was recorded separately as $\mathrm{kg}$ plot $^{-1}$ and then converted in $\mathrm{q} \mathrm{ha}{ }^{-1}$.After removal of cobs from stalks, maize stover was cut from ground level with the help of the sickles and was allowed to dry in sun. After sun-drying the weight were taken. Thus the stover yield plot $^{-1}$ was calculated which later expressed in $\mathrm{q} \mathrm{ha}{ }^{-1}$. The total cob yield and green fodder yield of each net plot was recorded and was expressed as biomass yield in $\mathrm{q} \mathrm{ha} \mathrm{ha}^{-1}$.Harvest index was calculated by dividing the economic yield i.e. grain yield to the biological yield i.e. grain yield + stover yield. The statistical analysis was done as per method described by Gomez and Gomez (1984).

\section{Results and Discussion}

\section{Growth parameters}

Analysis of variance showed that the periodic plant height of the crop went on increasing up to harvest and the magnitude of increase was more than double from 30 and 60 DAS irrespective of treatments. The results revealed that the plant height $(187.5 \mathrm{~cm})$ recorded with RDF was significantly higher than other treatments but at par with $75 \%$ $\mathrm{RDF}+\mathrm{FYM} @ 10 \mathrm{t} \mathrm{ha}^{-1}+$ Azospirillium + PSB + KSB and recorded a height of (184.8 $\mathrm{cm})$. Significant effect on the increase on the plant height in pop corn with the application of NPK may be attributed to the fact that nitrogen being an essential constituent of plant tissue favours rapid cell division and its enlargement, which together with the adequate quantity of phosphorus and potassium helps in the rapid cell division and better development of the cell size. Further, the beneficial effect of FYM may be attributed to the fact that it supplied available plant nutrients and also had solubilizing effect on fixed forms of nutrients especially phosphorus in soil (Ganai and Singh, 1988). The results are in close conformity with findings of Kumawat et al., (2014).

Table.1 Physico-chemical properties of soil of experimental field

\begin{tabular}{|l|l|l|l|l|l|l|l|}
\hline Depth & Texture & $\mathbf{E C}_{\text {Ds/m }}$ & $\mathbf{p H}$ & $\mathbf{O . C} \%$ & $\mathbf{N \%}$ & $\mathbf{P \%}$ & K\% \\
\hline $\mathbf{0 - 3 0} \mathbf{c m}$ & $\begin{array}{l}\text { Silty } \\
\text { clay } \\
\text { loam }\end{array}$ & 0.44 & 6.60 & 0.74 & 243.2 & 20.5 & 160 \\
\hline
\end{tabular}


Table.2 Effect of oganic and inorganic sources of nutrients on growth, and yield attributes of pop corn (Zea mays everta)

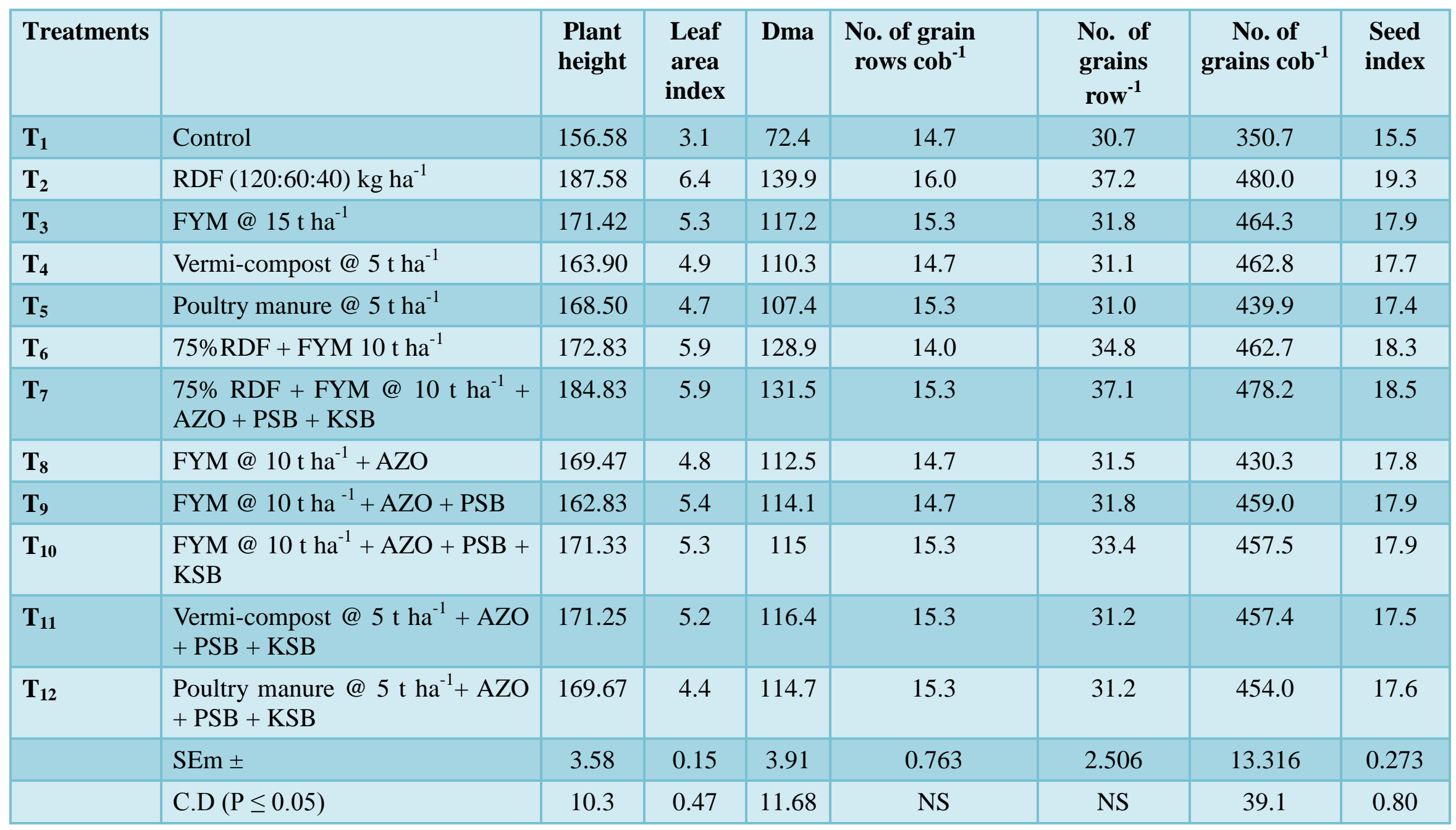


Table.3 Influence of organic and inorganic sources of nutrients on grain yield, stover yield, biological yield and harvest index (\%) of popcorn (Zea mays everta)

\begin{tabular}{|c|c|c|c|c|c|}
\hline Treatments & & $\begin{array}{l}\text { Grain yield } \\
\qquad\left(\text { qha }^{-1}\right)\end{array}$ & $\begin{array}{l}\text { Stover yield } \\
\quad\left(\text { qha }^{-1}\right)\end{array}$ & $\begin{array}{l}\text { Biological yield } \\
\qquad\left(\text { qha }^{-1}\right)\end{array}$ & $\begin{array}{c}\text { Harvest index } \\
(\%)\end{array}$ \\
\hline $\mathbf{T}_{1}$ & Control & 22.4 & 66.1 & 88.57 & 0.253 \\
\hline $\mathbf{T}_{2}$ & RDF (120:60:40) kg ha ${ }^{-1}$ & 38.8 & 110.2 & 148.28 & 0.262 \\
\hline $\mathbf{T}_{\mathbf{3}}$ & FYM@15 tha ${ }^{-1}$ & 32.2 & 92.2 & 124.63 & 0.258 \\
\hline $\mathbf{T}_{4}$ & Vermi-compost @ $5 \mathrm{tha}^{-1}$ & 28 & 85.5 & 116.4 & 0.242 \\
\hline $\mathbf{T}_{\mathbf{5}}$ & Poultry manure@ 5 t ha ${ }^{-1}$ & 27.5 & 84.1 & 113.52 & 0.242 \\
\hline $\mathbf{T}_{6}$ & $75 \%$ RDF + FYM $10 \mathrm{t} \mathrm{ha}^{-1}$ & 35.4 & 103.4 & 138.86 & 0.255 \\
\hline $\mathbf{T}_{7}$ & $\begin{array}{l}75 \% \mathrm{RDF}+\mathrm{FYM} @ 10 \mathrm{tha}^{-1}+ \\
\mathrm{AZO}+\mathrm{PSB}+\mathrm{KSB}\end{array}$ & 35.5 & 104.2 & 139.69 & 0.255 \\
\hline $\mathbf{T}_{8}$ & FYM @ $10 \mathrm{tha}^{-1}+\mathrm{AZO}$ & 29 & 88.3 & 117 & 0.248 \\
\hline $\mathbf{T}_{9}$ & FYM @ $10 \mathrm{tha}^{-1}+\mathrm{AZO}+\mathrm{PSB}$ & 28.6 & 84.2 & 112.79 & 0.253 \\
\hline $\mathbf{T}_{10}$ & $\begin{array}{l}\text { FYM @ } 10 \mathrm{tha}^{-1}+\mathrm{AZO}+\mathrm{PSB}+ \\
\mathrm{KSB}\end{array}$ & 31.4 & 90.1 & 121.5 & 0.258 \\
\hline $\mathbf{T}_{11}$ & $\begin{array}{l}\text { Vermi-compost @ } 5 \mathrm{tha}^{-1}+\mathrm{AZO}+ \\
\mathrm{PSB}+\mathrm{KSB}\end{array}$ & 30.1 & 88.4 & 118.5 & 0.254 \\
\hline \multirow[t]{3}{*}{$T_{12}$} & $\begin{array}{l}\text { Poultry manure @ } 5 \mathrm{t} \mathrm{ha}^{-1}+\mathrm{AZO}+ \\
\mathrm{PSB}+\mathrm{KSB}\end{array}$ & 31 & 88.4 & 119.4 & 0.259 \\
\hline & $\mathrm{SEm} \pm$ & 1.15 & 2.89 & 3.93 & 0.01 \\
\hline & C.D $(\mathrm{P} \leq 0.05)$ & 3.37 & 8.49 & 11.52 & 0.03 \\
\hline
\end{tabular}


Table.4 Relative economics of popcorn (hectare basis) as influenced by various treatments (Mean)

\begin{tabular}{|c|c|c|c|c|c|}
\hline Treatments & & $\begin{array}{c}\text { Cost of } \\
\text { Cultivation } \\
\left.(\operatorname{Rs~ha})^{-1}\right)\end{array}$ & $\begin{array}{l}\text { Gross returns } \\
\qquad\left(\mathrm{Rs} \mathrm{ha}^{-1}\right)\end{array}$ & $\begin{array}{l}\text { Net returns } \\
\left(\mathrm{Rs} \mathrm{ha}^{-1}\right)\end{array}$ & B : C ratio \\
\hline $\mathbf{T}_{1}$ & Control & 27690 & 85010 & 57320 & 3.1 \\
\hline $\mathbf{T}_{2}$ & RDF (120:60:40) $\mathrm{kg} \mathrm{ha}^{-1}$ & 36540 & 134690 & 98150 & 3.6 \\
\hline $\mathbf{T}_{3}$ & FYM@15 tha ${ }^{-1}$ & 44190 & 110330 & 66140 & 2.5 \\
\hline $\mathbf{T}_{4}$ & Vermi-compost@5 tha ${ }^{-1}$ & 89190 & 106550 & 17360 & 1.2 \\
\hline $\mathbf{T}_{5}$ & Poultrymanure@5 tha ${ }^{-1}$ & 54190 & 104660 & 50470 & 1.9 \\
\hline $\mathbf{T}_{6}$ & $75 \%$ RDF + FYM $10 \mathrm{t} \mathrm{ha}^{-1}$ & 42390 & 134240 & 91850 & 3.2 \\
\hline $\mathbf{T}_{7}$ & $\begin{array}{l}75 \% \mathrm{RDF}+\mathrm{FYM} @ 10 \mathrm{tha}^{-1}+\mathrm{AZO}+\mathrm{PSB}+ \\
\mathrm{KSB}\end{array}$ & 42910 & 146820 & 103910 & 3.4 \\
\hline $\mathbf{T}_{8}$ & FYM@10 tha ${ }^{-1}+\mathrm{AZO}$ & 63555 & 108520 & 44965 & 1.7 \\
\hline $\mathbf{T}_{9}$ & FYM@10 tha ${ }^{-1}+\mathrm{AZO}+\mathrm{PSB}$ & 59370 & 114190 & 54820 & 1.9 \\
\hline $\mathbf{T}_{10}$ & FYM@10 tha ${ }^{-1}+\mathrm{AZO}+\mathrm{PSB}+\mathrm{KSB}$ & 59550 & 121920 & 62370 & 2.0 \\
\hline $\mathbf{T}_{11}$ & Vermi-compost@5 tha ${ }^{-1}+\mathrm{AZO}+\mathrm{PSB}+\mathrm{KSB}$ & 59730 & 118910 & 59180 & 2.0 \\
\hline $\mathbf{T}_{12}$ & Poultrymanure@ $5 \mathrm{t} \mathrm{ha}^{-1}+\mathrm{AZO}+\mathrm{PSB}+\mathrm{KSB}$ & 51730 & 117340 & 65610 & 2.3 \\
\hline
\end{tabular}


The increase in plant height with increase in nitrogen levels and FYM application has also been reported by Suthar et al., (2014) and Meena et al., (2017). Furthermore treatment $\left(\mathrm{T}_{6}\right),\left(\mathrm{T}_{3}\right)$ and $\left(\mathrm{T}_{10}\right)$ were at par with each other and recoded a height of $172.8 \mathrm{~cm}$, $171.42 \mathrm{~cm}$ and $171.2 \mathrm{~cm}$ at harvest, respectively. However, lowest plant height $(156.58 \mathrm{~cm})$ was recorded in control $\left(\mathrm{T}_{1}\right)$ at harvest stage. Also the treatments $\left(\mathrm{T}_{11}\right),\left(\mathrm{T}_{12}\right)$, $\left(\mathrm{T}_{9}\right),\left(\mathrm{T}_{8}\right),\left(\mathrm{T}_{5}\right),\left(\mathrm{T}_{4}\right)$ were at par with each other. The data revealed that leaf area index increased consistently up to 60 DAS and thereafter decreased irrespective of treatments. The results revealed that the leaf area index (6.68) recorded with $\left(\mathrm{T}_{2}\right)$ was significantly higher than other treatments but at par with $\left(\mathrm{T}_{7}\right)$ and recorded a leaf area index (6.15). It may be attributed to better utilization of available nutrient resources which might have increased the number of green leaves and in turn enhanced leaf area index (LAI). It is also a well known fact that increase in plant height tend to increase number of leaves plant ${ }^{-1}$ which in turn increase LAI. Pathak et al., (2002), Afifi et al., (2003) and Kumar et al., (2005) also reported increased leaf area index by combined application of organic and inorganic fertilizers. The results confirm findings of Suthar et al., (2014) and Meena et al., (2017). Furthermore treatment $\left(\mathrm{T}_{6}\right),\left(\mathrm{T}_{3}\right)$ and (T10) were at par with each other were par with each other and recorded a leaf area index of $6.09,5.58$ and 5.58 at 60 DAS, respectively. However, lowest leaf area index (3.3) was recorded in control at 60 DAS. $\left(\mathrm{T}_{11}\right),\left(\mathrm{T}_{12}\right),\left(\mathrm{T}_{9}\right),\left(\mathrm{T}_{8}\right),\left(\mathrm{T}_{5}\right),\left(\mathrm{T}_{4}\right)$ were at par with each other. Dry matter production went on increasing with the advancement in the growth of crop up to harvest and the magnitude of increase was more than double from 30 DAS to 60 DAS in all the treatments. At harvest the dry matter production recorded under treatment RDF $\left(120 \mathrm{~N}: 60 \mathrm{P}_{2} \mathrm{O}_{5}: 40\right.$ $\left.\mathrm{K}_{2} \mathrm{O}\right) \mathrm{kg} \mathrm{ha}^{-1}$ was significantly higher than other treatments but was at par with $75 \%$ $\mathrm{RDF}+\mathrm{FYM} @ 10 \mathrm{t} \mathrm{ha}^{-1}+$ Azospirillium + $\mathrm{PSB}+\mathrm{KSB}$. However, at 60 DAS and 90 DAS the dry matter accumulation of RDF $\left(120 \mathrm{~N}: 60 \quad \mathrm{P}_{2} \mathrm{O}_{5}: 40 \quad \mathrm{~K}_{2} \mathrm{O}\right) \quad \mathrm{kg}^{-1}$ has $\mathrm{T}_{12}$ significantly higher than $\left(\mathrm{T}_{7}\right)$ followed by $\left(\mathrm{T}_{6}\right),\left(\mathrm{T}_{3}\right),\left(\mathrm{T}_{10}\right),\left(\mathrm{T}_{11}\right),\left(\mathrm{T}_{12}\right),\left(\mathrm{T}_{4}\right)$, and $\left(\mathrm{T}_{11}\right)$. The study also revealed that significantly lowest periodic dry matter was observed under unfertilized control. The larger canopy development and increased plant height with 75\% RDF + FYM @ $10 \mathrm{t} \mathrm{ha}^{-1}+$ Azospirillium + PSB + KSB fertility level might have increased interception, absorption and utilization of radiant energy which in turn increased overall growth, photosynthesis, and accumulation of dry matter. The results are in agreement with the findings of Singh et al., (2007) and Kumar and Dhar (2010). It was also found that magnitude of increase in dry matter was more pronounced between early stages of crop growth up to silking stage thereafter the growth in dry matter production was sluggish up to harvest. Though the grand vegetative growth period of the crop lasted up to silking stage but the continued production of pop corn cobs (reproductive phase) stretched the overall grand growth period up to 70 DAS. The results are in close conformity with findings of Kumawat et al., (2014), Suthar et al., (2014) and Meena et al., (2017).

\section{Yield and yield attributes}

The data (Table 2) indicated that various yield contributing characters of pop corn viz., number of cobs plant ${ }^{-1}$, cob girth, cob weight and cob length (with and without husk) were significantly higher with the application of $\left(T_{7}\right)$ fertility level compared to lower fertility levels which in turn resulted in higher cob yield (with and without husk) under the same treatment. The yield potential of pop corn crop is decided by its growth and yield components. This might be attributed to the 
sufficient availability of nutrients under treatment $\left(\mathrm{T}_{7}\right)$ compared to lower fertility levels resulting in higher values of leaf area index, total dry matter production and yield contributing characters which ultimately led to increase in pop corn yield. These results are in conformity with the findings of Afifi et al., (2003), Kumar and Thakur (2004), AICMIP (2004 and 2006) and Dadarwal et al., (2009). The result showed that combined effect of inorganic nutrients (NPK) and organic fertilization (FYM + Azospirillium + PSB + KSB) played very important role in increasing cob yield due to their synergistic effect. This indicated that pop corn responded well to integrated nutrient management especially to FYM + Azospirillium + PSB + KSB which might be owing to favorable effect of FYM on soil condition and synchronized release of plant nutrients throughout the crop period and further inorganic nutrients have positive influence on source-sink relationship as evident from remarkable improvement in plant height and dry matter accumulation and ultimately cob yield particularly under $75 \%$ $\mathrm{RDF}+\mathrm{FYM} @ 10 \mathrm{t} \mathrm{ha}^{-1}+$ Azospirillium + PSB + KSB fertility level. The results are in line with findings reported by Singh et al., (2009), Das et al., (2008) and Balai et al., (2011). Application of treatment $\left(\mathrm{T}_{7}\right)$ fertility level recorded significantly higher fodder yield (Table 3) which might be attributed to the luxuriant and vigorous growth of crop as witnessed from improved growth character, viz., plant height, stem diameter, leaf area index and dry matter accumulation at higher fertility levels which might have contributed to higher green fodder yield. For every additional application of nutrients in an integrated form along with FYM + Azospirillium $+\mathrm{PSB}+\mathrm{KSB}$ there was improvement in vegetative vigour of plant which ultimately increased the green fodder yield. Panwar (2008) also made similar findings.

\section{Relative economics}

The present investigation revealed that highest gross returns of Rs.1,46820, net return of Rs.1,03910 was realized from the treatment $\left(\mathrm{T}_{7}\right)$ but highest benefit: cost ratio (3.6) was realized from treatment $\left(T_{2}\right)$ which was having least significant difference from benefit: cost ratio (3.4) of treatment $\left(\mathrm{T}_{7}\right)$, where as the lowest benefit cost ratio (1.2) was noticed in $\left(\mathrm{T}_{4}\right)$. Ramesh Naik et al., (2008), Ashok et al., (2008), Kumar and Thakur (2004) and Ravindra Singh and Agarwal (2004) also reported the similar results.

In conclusion the economic analysis of the treatments indicated that highest net returns of Rs. 103910and benefit: cost ratio of Rs. 3.4 was realized with application of treatment $\left(\mathrm{T}_{7}\right)$. So, we suggest application of $\left(\mathrm{T}_{7}\right)$ over $\left(\mathrm{T}_{2}\right)$ because of its considerable influence on improving soil health and maintaining ecological balance and also with better gross returns and net returns. In view of this, it may be concluded that for obtaining maximum economic and biological yield in pop corn, it needs to be fertilized with treatment $\left(T_{7}\right)$. However, before giving final recommendations, the investigation needs to be carried out at different agro-climatic regions of the valley to arrive at final conclusion.

\section{References}

Afifi MH, Manal FM Gomaa AM.Effect of biofertilizer under different levels of chemical fertilizers on maize (Zea mays L). Annals of AgriculturalScienceMoshtonor. 2003;41: 1411-1420.

AICMIP, $47^{\text {th }}$ Annual Progress Report, All India Coordinated Maize Improvement Project, Directorate of Maize Research, Pusa Campus, New Delhi. 2004. pp. 
75.

AICMIP, 49 ${ }^{\text {th }}$ Annual Progress Report, 200506. All India Coordinated Maize Improvement Project, Directorate of Maize Research, Pusa Campus, New Delhi .2006; 76.

Awotundun JS, Comparative Effects of organic and inorganic fertilizer on the yield of pop-corn. In: Proceedings of the 29th Annual Conference of the Soil science society of Nigeria. December, 6th-10th, 2004. University of Agriculture Abeokuta, Nigeria. 2005. 175-179.

Balai ML, Verma A, Nepalia V Kanthaliya PC. Productivity and quality of maize (Zea mays L.) as influenced by integrated nutrient management under continuous cropping and fertilization. Indian Journal of Agricultural Sciences. 2011;81: 374-376.

Banik S,Dey BK. Available phosphate content of an alluvial soil as influenced by inoculation of some isolated phosphate solubilizing microorganisms. Plant and Soil. 1982;69: 353-364.

Belay A, Classens AS, Wehner FC, De Beer JM. Influence of residual manures on selected nutrient elements and microbial composition of soil under long-term crop rotation. South African Journal of Plant and Soil 2001;18: 1-6.

Chand P, Sharma NN. Constant for determining leaf area index in maize. Indian Journal of Agronomy1976;21(2): 171-173.

Dadarwal RS, Jain NK, Singh D. Integrated nutrient management in baby corn (Zea mays L.). Indian Journal of Agricultural Sciences2009;79: 10231025.

DaA, Lenka NK, Sudhishri S, Patnaik US. Influence of integrated nutrient management on production, economics and soil properties in tomato
(Lycopersicon esculentum) under onfarm condition in Eastern Ghats of Orissa. Indian Journal of Agricultural Sciences 2008;78: 40-43.

Directorate of Economics and Statistics, DAC and FW. Pocket Book of Agricultural Statistics. 2014-2015; . 58.

FAO, http: //faostat.fao.org. 2015.

Ganai BA, Singh CM. Effect of FYM applied to rice-wheat rotation on physiochemical properties of soil. Indian Journal of Agronomy. 1988;33(3): 327-329.

GomezKA, Gomez AA. Statistical Procedures for Agricultural Research, $2^{\mathrm{ND}}$ edition, a Willey International Science Publication, New York (USA). 1984.

Kulkarni JH, Joshi PK.Rhizobium inoculation studies in groundnut. Problems and prospects in bio-fertilizerspotentialities and problems (Eds. S. P. Sen and P. Patil) Naya Prakashan Culcutta pp. 1988;51-56.

Kumar A, Dhar S. Evaluation of organic and inorganic sources of nutrients in maize (Zea mays L.) and their residual effect on wheat (Triticum aestivum) under different fertility levels. Indian Journal of Agricultural Sciences2010;80: 364371.

Kumar A, Thakur KS, Sharm S. Integrated nutrient management in maize (Zea mays)-gobhi sarson (Brassica napus ssp oleifera var. annua) cropping system under rainfed condition. Indian Journal of Agronomy2005;50: 274277.

Kumar A, Thakur SK.. Effect of integrated nutrient management on promising composite maize varieties under rainfed mid-hill conditions of Himachal Pradesh. Indian Journal of Agricultural Sciences.2004;74(1): 4042.

Kumawat P, Kaushik MK, Singh D, Kumawat K. Yield, nutrient content, uptake and 
quality of sweet corn varieties as influenced by nitrogen and phosphorus fertilization under southern Rajasthan condition. Annals of Agri-Biology Research.2014;19(1): 67-69.

Meena AK, Chouhan D, Singh D, Nepalia V. Response of pop corn (Zeamays everta) varieties to varying plant densities and fertility levels. IndianJournal of Agronomy.2017;62(1): 43-46.

Mishra M, Patjoshi AK, Jena D. Effect of biofertilization on production of maize. Indian Journal of Agronomy1998;43 (2): 307-310.

Panwar AS.. Effect of integrated nutrient management in maize (Zea mays L.)mustard (Brassica campestris var. toria) cropping system in mid hills altitude. Indian Journal of Agricultural Sciences .2008;78: 27-31.

Pathak SK, Singh SB, Singh SN. Effect of integrated nutrient management on growth, yield and economics in maizewheat cropping system. Indian Journal of Agronomy.2002. 47(3): 325-332.

Pathak SK, Singh SB, Jha BN, Sharma RP. Effect of nutrient management on nutrient uptake and changes in soil fertility in maize-wheat cropping system. Indian Journal of Agronomy. 2005.50: 269-273.

Ramesh, NaikD, Halepyati AS, Pujari BT.. Effect of organic manures and fertilizer levels on seed yield and economics of safflower (Carthamus tinctorius L.). Karnataka Journal of Agricultural Sciences2008;21(1): 104-105.
Rayar AJ. Sustainable Agriculture in subsharan Africa. The Role of soil productivity. AJR Publishers India 2000; 104-156.

RavindraS, Agrawal SK.. Effect of organic manuring and nitrogen fertilization on productivity and economics of wheat (Triticum aestivum L.). Indian Journal of Agronomy .2004 49(1): 49-52.

Reeves DW. The role of soil organic matter in maintaining soil quality in continuous cropping systems. Soil Tillage Research.1997;101: 31-36.

Singh D, Yadav LR.. Effect of organic manures, chemical fertilizers and phosphorus sources on quality protein maize (Zea mays L..) Agronomy Digest.2007; 7: 15-17.

Singh RK, Singh SK, Singh LB. Integrated nitrogen management in wheat (Triticum aestivum). Indian Journal of Agronomy.2007;53: 124-126.

Singh U, Saad AA, Singh SR. Effect of integrated nutrient management on growth and yield of maize (Zea mays L.) under rainfed conditions in Kashmir valley. Agronomy Digest .2007; 7: 13.

Suthar M, Singh D, Nepalia V, Singh AK.. Performance of sweet corn (Zea mays L Ssp saccharata) at varying fertility levels. Forage Research2014;38(2): 115-118.

Suthar M, Singh D, Nepalia V, Singh AK.. Performance of sweet corn (Zea mays) varieties under varying fertility levels. Indian Journal of Agronomy. 2014;59(1): 168-170.

\section{How to cite this article:}

Sadaf Iqbal, Zahida Rashid, Manzoor Ganai, A. A. Saad, R. H. Kanth, Rais Bhat, Tahir Sheikh, Javaid Ahmad Bhat and Tanveer. 2020. Response of Growth, Yield and Yield Attributes of Popcorn (Zea mays everta) to Organic and Inorganic Sources of Nutrients. Int.J.Curr.Microbiol.App.Sci. 9(07): 4024-4034. doi: https://doi.org/10.20546/ijcmas.2020.907.472 